\title{
Middleton beyond the Canon
}

Daniela Guardamagna

\section{(2) OpenEdition}

Journals

Electronic version

URL: http://journals.openedition.org/shakespeare/3394

DOI: 10.4000/shakespeare.3394

ISSN: 2271-6424

\section{Publisher}

Société Française Shakespeare

\section{Electronic reference}

Daniela Guardamagna, "Middleton beyond the Canon », Actes des congrès de la Société française Shakespeare [Online], 33 | 2015, Online since 10 October 2015, connection on 08 June 2020. URL http://journals.openedition.org/shakespeare/3394 ; DOI : https://doi.org/10.4000/shakespeare.3394

This text was automatically generated on 8 June 2020

(c) SFS 


\title{
Middleton beyond the Canon
}

\author{
Daniela Guardamagna
}

1 The old canon of Thomas Middleton ${ }^{1}$ has been deeply modified in the last forty years by attribution studies, by the analysis of philologists and the work of MacDonald P. Jackson, David Lake and Roger Holdsworth, ${ }^{2}$ and especially after the issue of what has been defined as "Middleton's First Folio", that is his Collected Works and Textual Companion, edited by Gary Taylor and John Lavagnino. ${ }^{3}$

2 Critics are now aware that there are many clues hinting at the fact that the "new Middleton' is very different from the author that was proposed till the last decades of the $20^{\text {th }}$ century, that is the cold, misogynist, clinical analyst of the society around him ("a $17^{\text {th }}$-century Ibsen or Zola", as he was defined ${ }^{4}$ ), and that the new figure presents striking features which greatly modify our perception of his work.

In this paper I will concentrate on a specific instance concerning the new canon: the modification of female characters that becomes apparent in Middleton's writing, considering the new plays, the tragedies in particular, that have been definitely attributed to him in the 2007 Collected Works.

4 I must briefly deal first of all with the 'old' perception of Middleton: though a few of the 'new' plays were attributed to him in the 1970s or 1980s (The Revenger's Tragedy being one of them), he was known as an author who arrived at tragedy very late in life, a writer of satires and city comedies (and of some very little studied tragicomedies) who rather surprisingly turned to tragedy in the very last years of his presence on London stages. As Gary Taylor wrote, "Middleton's career has been falsely divided into two tones - early 'city comedy' and late 'Jacobean tragedy' - which define the protocols for reading him; critics have not known how to read texts which do not fit those protocols". ${ }^{5}$ This is why, for instance, tragicomedies have been mostly neglected.

The following table identifies the main modifications of his canon. ${ }^{6}$

\begin{tabular}{|l|l|}
\hline TRADITIONAL CANON & NEW CANON \\
\hline $\begin{array}{l}\text { The Family of Love (1602), } \\
\text { satire; }\end{array}$ & Not by Middleton: probably by Lording Barry; \\
\hline
\end{tabular}




\begin{tabular}{|c|c|}
\hline $\begin{array}{l}\text { Blurt Master Constable (1602), } \\
\text { comedy; }\end{array}$ & Not by Middleton: probably by Dekker; \\
\hline $\begin{array}{l}\text { The Phoenix (1603-1604), } \\
\text { tragicomedy; }\end{array}$ & The Phoenix (1603-1604), tragicomedy; \\
\hline $\begin{array}{l}\text { The Patient Man and the Honest } \\
\text { Whore (1604), comedy; }\end{array}$ & The Patient Man and the Honest Whore (1604), comedy; \\
\hline $\begin{array}{l}\text { The Honest Whore Part II } \\
\text { (1605-1606), comedy; }\end{array}$ & Not by Middleton: probably by Dekker; \\
\hline $\begin{array}{l}\text { Michaelmas Term (1605), city } \\
\text { comedy; }\end{array}$ & Michaelmas Term (1604), city comedy; \\
\hline $\begin{array}{l}\text { A Mad World, My Masters } \\
\text { (1605-1606), city comedy; }\end{array}$ & A Mad World, My Masters (1605), city comedy; \\
\hline \multirow[t]{5}{*}{$\begin{array}{l}\text { A Trick to Catch the Old One } \\
\text { (1606), city comedy; }\end{array}$} & A Trick to Catch the Old One (1605), city comedy; \\
\hline & A Yorkshire Tragedy (1605), tragedy; \\
\hline & $\begin{array}{l}\text { The Puritan, or The Puritan Widow, or The Widow of Watling Street } \\
\text { (1606), city comedy; }\end{array}$ \\
\hline & The Revenger's Tragedy (1606), tragedy; \\
\hline & $\begin{array}{l}\text { Collaboration with Shakespeare to Timon of Athens (1605-1608), } \\
\text { tragedy; }\end{array}$ \\
\hline \multirow[t]{2}{*}{$\begin{array}{l}\text { Your Five Gallants (1607), } \\
\text { comedy; }\end{array}$} & Your Five Gallants (1607), comedy; \\
\hline & The Bloody Banquet (1609), tragedy; \\
\hline \multirow[t]{2}{*}{$\begin{array}{l}\text { The Roaring Girl (1611), city } \\
\text { comedy; }\end{array}$} & The Roaring Girl (1611), city comedy; \\
\hline & $\begin{array}{l}\text { The Lady's Tragedy (traditional title The Second Maiden's } \\
\text { Tragedy, 1611), tragedy; }\end{array}$ \\
\hline $\begin{array}{l}\text { No Wit, No Help Like a Woman's } \\
\text { (1611), comedy; }\end{array}$ & No Wit, No Help Like a Woman's (1611), comedy; \\
\hline $\begin{array}{l}\text { A Chaste Maid in Cheapside } \\
\text { (1613), city comedy; }\end{array}$ & A Chaste Maid in Cheapside (1613), city comedy; \\
\hline $\begin{array}{l}\text { Wit at Several Weapons (1613), } \\
\text { comedy; }\end{array}$ & Wit at Several Weapons (late 1613), comedy; \\
\hline $\begin{array}{l}\text { More Dissemblers beside Women } \\
\text { (1614), comedy; }\end{array}$ & More Dissemblers beside Women (1614), comedy; \\
\hline $\begin{array}{l}\text { The Widow (1615-1616), } \\
\text { comedy; }\end{array}$ & The Widow (1615-1616), romantic comedy; \\
\hline The Witch (1616), tragicomedy; & The Witch (1616), tragicomedy; \\
\hline \multirow[t]{2}{*}{$\begin{array}{l}\text { A Fair Quarrel (1616), } \\
\text { tragicomedy; }\end{array}$} & A Fair Quarrel (late 1616), tragicomedy; \\
\hline & Adaptation of Shakespeare's Macbeth, 1616; \\
\hline
\end{tabular}




\begin{tabular}{|l|l|}
\hline $\begin{array}{l}\text { The Old Law (1618), } \\
\text { tragicomedy; }\end{array}$ & The Old Law (1618-1619), tragicomedy; \\
\hline Hengist (1616-1620), tragedy; & Hengist (1620), tragedy; \\
\hline $\begin{array}{l}\text { Adaptation of Shakespeare's Measure for Measure (1621), } \\
\text { tragicomedy; }\end{array}$ \\
\hline $\begin{array}{l}\text { Anything for a Quiet Life (1621), } \\
\text { comedy; }\end{array}$ & Anything for a Quiet Life (late 1621), comedy; \\
\hline $\begin{array}{l}\text { Women Beware Women (1621), } \\
\text { tragedy; }\end{array}$ & Women Beware Women (1621), tragedy; \\
\hline The Changeling (1622), tragedy; & The Changeling (May 1622), tragedy; \\
\hline $\begin{array}{l}\text { The Nice Valour (1622), } \\
\text { tragicomedy; }\end{array}$ & The Nice Valour (September 1622), tragicomedy; \\
\hline $\begin{array}{l}\text { The Spanish Gipsy (1623), } \\
\text { tragicomedy; }\end{array}$ & $\begin{array}{l}\text { The Spanish Gipsy, tragicomedy, co-authored with John Ford, } \\
\text { Middleton; }\end{array}$ \\
\hline A Game at Chess (1624), satire. & A Game at Chess (1624), satire. \\
\hline
\end{tabular}

6 As I hope is apparent from this table, the old canon presents a long series of satires and comedies (mostly city comedies) in the first years, a series of tragicomedies in the middle years, then all of a sudden the tragedy Hengist $^{7}$ (very little studied, probably because it was disconcerting to critics, if we follow Taylor's statement), then the two tragic masterpieces, Women Beware Women and The Changeling, and at last a new political satire, A Game at Chess; in the new canon, no less than four tragedies (five if we consider the collaboration to Shakespeare's Timon) have been inserted, thus creating a much more regular pattern, which gives us a new insight into Middleton's development, use of genre and work on characters.

7 It is quite surprising how Middleton's figure changes in the light of the new plays: he certainly remains the clear-minded analyst of the London of his time, concentrating on the emphasis on economic problems and relationships among the social classes; but he is also revealed as a writer who can shape his characters with unusually lurid violence, with necrophiliac loves, poisoned kisses, murder of innocent babes and cannibalic feasts.

8 Middleton's treatment of female characters is also deeply modified. Considering the plays of the traditional canon, in the tragedies the female protagonists are often cruel, sometimes murderers, most of the time taking advantage of their beauty to wreck the life of men who cross their path, and in turn their own: scatter-brained, morally blind sinners who only follow their desires (as the "fair murderess" Beatrice-Joanna in The Changeling), who mistake for love a passing attraction which does not survive the test of family life (as Bianca in Women Beware Women), or work on their sexual appeal to obtain power (Beatrice-Joanna again, but also the cruel Roxena in Hengist); in the comedies and in most tragicomedies, the positive characters of the traditional canon tend with few exceptions to be shallow, passively virtuous amorose who have to bear the burden of unrequited courtship and wait to be saved by their lovers. The active female characters depicted with human sympathy in the traditional canon were mostly the 
Courtesans of city comedies, generous but sinful; one should add Thomasine from Michaelmas Term (who is disposed of with a brief "Oh God" when she finds she must return to her miserly and rough husband), Moll Cutpurse from The Roaring Girl (an outspoken, brave and active woman, but a thief of far from spotless behaviour), and the cross-dressed heroine of No Wit, No Help like a Woman's. Most women, sinning, frail objects of temptation, yielding to it themselves, were described with words and attitudes perfectly compatible with the 'fallen rib' vision of misogynist religions.

In the new canon, misogyny remains frequent, and misogynist sallies are present in most plays: "Are you yet constant? Shame your sex, and be so" (The Bloody Banquet, I.iii. 599); "Wives are but made to go to bed and feed" (The Revenger's Tragedy, I.i.131); “...[I] admire / That heaven can frame a creature like a woman / And she be constant, seeing most are common" (The Bloody Banquet, I.i.137-139); "But 'twas decreed before the world began / That they [women] should be the hooks to catch at men" (The Revenger's Tragedy, II.i.255-256). But if in the three tragedies of the old canon the female protagonists of the main plot were all negative characters, in the newly-added tragedies the typology of female protagonists changes and multiplies, preventing the audience, the reader, and the critic from falling into obvious responses and stereotyped labels. (This article is devoted to Middleton's plays; an important role in his general canon is of course that of Lucrece in The Ghost of Lucrece, where the sharp contrast between Shakespeare's and Middleton's heroine is worth analysing. ${ }^{10}$ )

Following the chronological order of the 'new plays', I will briefly discuss the female protagonists of A Yorkshire Tragedy, The Revenger's Tragedy, The Bloody Banquet and The Lady's Tragedy.

11 The first tragedy that has been newly attributed to Middleton is A Yorkshire Tragedy, written almost certainly in 1605 . Very brief, based on a contemporary event (the Calverley murder) and on the pamphlet derived from it, it is a domestic tragedy set in a bourgeois milieu: it tells the story of a man who, ruined by drinking and gaming, is pushed by despair to killing two of his children, trying to kill the third and his innocent wife. She is a patient, Griselda-like heroine, who bears her fate with a love beyond common sense and logic; her self-denial is so complete as to become almost heroic, and leads the man to repent and save his own soul. This is probably the least interesting female character in the new plays, as the text - which was for some time considered one of Shakespeare's apocrypha - gives space and colour only to the character of the husband.

12 The second newly added play is The Revenger's Tragedy, which deals with four female characters, none of which has a prominent role, but where we do find something new comparing them to the old plays. They are the unfaithful Duchess; Gloriana, the dead fiancée of the protagonist Vindice; his mother Gratiana; his sister Castiza. The Duchess could be a character from the former tragedies: lustful, faithless, she is in love with the bastard son of her husband the Duke, and is caught committing adultery with him. Nothing new so far, except the lack of pretence: open sin and no hypocrisy, differently from what happens to Beatrice-Joanna and others. Coming to the second female character, Gloriana, when the play starts she is already dead, and the scene opens with her former fiancé Vindice, meditating Hamlet-like on death, fondling her skull and praising her beauty and virtue, which have been the cause of her murder, because the Duke tried to seduce her and, when she refused to yield, had her poisoned. After the wife of the Yorkshire Tragedy, this is the second virtuous woman in a tragedy by 
Middleton (though certainly, being dead, she is at least as passive as the heroines of his comedies are).

Then there is Vindice's mother Gratiana, who is again a sinner: induced by her poverty and by the hope of obtaining a better social status, she accepts to try to convince her daughter to yield to the advances of the lecherous son of the Duke, whose speaking name is Lussurioso. ${ }^{11}$ When her sons reveal that they are aware of what she did and accuse her, she instantly repents, and poses quite unconvincingly as a future paragon for mothers.

Last, and more interesting, is the character of her daughter Castiza: her part is not a very prominent one either, as she only appears in two scenes of the tragedy; but her role is the most challenging in connection with my theme. She is a virgin in distress, coveted by Lussurioso; but she is not as passive as the virtuous young ladies we meet in many comedies and tragicomedies.

When Vindice presents himself to her in disguise, nominally to woo her on Lussurioso's behalf, she reacts bravely, with noble and scornful words:

I swore I'd put anger in my hand

And pass the virgin limits of myself

To him that next appeared in that base office [...].

Tell him my honour shall have a rich name

When several harlots shall share his with shame [...]

Farewell, commend me to him, in my hate! (II.i.31-39)

enriched with alliterating embellishments ("shall... shall share... shame"). She accompanies her words with a sound blow on her brother's face, to which Vindice provides the expected comic relief ("It is the sweetest box that e'er my nose came nigh", II.i.40). Later, she is not sure that her mother has really repented and abandoned the wicked idea of prostituting her to the son of the Duke, and Middleton grants her a metatheatrical solution which is normally allotted to male protagonists: the invention and the acting of a part to modify one's reality or to influence the behaviour of someone else. After a few violent, original, but helpless reactions to her mother's words ("I cry you mercy; lady I mistook you, / Pray, did you see my mother? [...] / Pray god I have not lost her", II.i.157-159; and later: "Mother, come from that poisonous woman there[!]", 235), she pretends to be persuaded and happily announces to her mother that she is now a new woman, anxious to go to bed with the Duke's son, and ready to please him with as wanton a behaviour as anybody can wish. To this sustained performance (about 50 lines) her mother reacts with horror, revealing the truth of her conversion. This is certainly not the core of the play, where the metatheatrical devices - masks and disguises - worn by her brother Vindice are far more relevant. But it is certainly a new aspect in a Middletonian female.

The performance of someone abusing himself to unmask the real aims and nature of the person $\mathrm{s} / \mathrm{he}$ is speaking to will probably remind us all of the Machiavellian scene between Malcolm and Macduff, where Macduff's reaction of horror at the supposed sins of Malcolm convinces the prince of his good faith; while the disguise of a son to cure the soul of a desperate parent, though certainly devoid of the psychological and existential depth of the model, reminds one of Edgar's disguise and of his words ("Why I do trifle thus with his despair, is done to cure it"12), echoed by the less striking but similar words of Castiza. Though we are not dealing in any depth with philological questions here, it must be remembered that The Revenger's Tragedy was acted by the 
King's Men in 1606, and that the likely dates of Lear's and Macbeth's productions (again of course staged by the King's Men) are late 1605 and 1606. Echoes, therefore, are far from accidental.

So, a female Middletonian character echoes two Shakespearean male ones. What one should ask oneself at this point is how frequently female characters are allowed the use of masks, disguises and creative lies in Elizabethan drama.

'Protective' lies are not the point: what we are briefly investigating is very different from the disguise of virgins in distress (from Viola in Twelfth Night to Ford's Eroclea in The Lover's Melancholy) who wear a manly attire to save their virtue and be safe in a possibly violent world. Nor do the dejected young women who are hopelessly in love with a man and disguise themselves to be near the object of their love, without any hope of conquering him (as Beaumont and Fletcher's Bellario, in love with Philaster in the eponymous play), concern us, because no active and challenging behaviour is presented, and no modification of reality is envisaged by the patient, Griselda-like heroines.

19 I can think of only one great female character which uses a disguise to obtain a concrete, important result in the real world: it is of course Shakespeare's Portia. ${ }^{13}$

20 I am not maintaining that Castiza's role in The Revenger's Tragedy is as central as that of Portia in The Merchant of Venice, nor that any Middletonian female character in this phase of the author's career can be as complex, vital and lacking in stereotypes as a character in Shakespeare. The Revenger's Tragedy's Castiza, though, is certainly a far cry from the poor helpless mother in The Phoenix or the 'chaste maid' of the Cheapside play, and opens the way to female protagonists who are remote from those in the 'old canon' Middleton.

21 We are now going to discuss briefly the protagonist of the third newly attributed tragedy, the wife of the Tyrant in The Bloody Banquet (probably written in 1609). Thetis is young and beautiful, and the old cruel Tyrant keeps her prisoner in their castle, surrounded by guards who should never leave her alone. Thetis proves unfaithful, meeting a young prisoner and falling in love with him. She tries to protect her fame having him masked and lying with him without revealing her identity; when her lover recognises her, she kills him. So far, the audience is not asked to sympathize with her, though the effective description of her anxiety regarding the unknown emotion she feels, the brief fight between a love she never experienced and the fear of being discovered, and the quivering soliloquies she utters on stage do not describe her as a hard-hearted virago we are expected to disapprove of sternly. She also has a very clear vision of her position, her dangers and her guilt, and does not deceive herself, which is the fatal fault of later Middletonian heroines (Bianca and Beatrice-Joanna).

We need not go into the details of the complex love-jealousy-hate plot that cause her discovery: she is found out by her husband, confesses, and is condemned to the frightful punishment which is an extreme version of the Senecan and Ovidian banquet: she is to feed on the body of her lover, drinking nothing but his blood, having no other nourishment till his flesh has been consumed.

23 This is the description of her public mortification, in front of the disguised enemies of the Tyrant:

A banquet brought in, and by it a small table for the [young] Queen. [...] Soft music. Enter the Tyrant with the [young] Queen, her hair loose; she makes a curtsy to the 
table. Sertorio brings in the flesh, with a skull all bloody. [She sits at the table, and begins to eat the flesh, and drink blood from the skull.] They all wonder (V.i)

The unfaithful wife is certainly guilty; but the Ophelia-like quality of her appearance in the last scene, ${ }^{14}$ her dishevelled hair, her silence, the pitiful curtsy with which she accepts to be part of the awful tableau in which her terrifying penance is enacted, are presented with an implicit compassion which does not allow the audience to fall on a simplified response.

Some critics, especially feminist ones, have commented on how in Middleton and other Jacobean authors the female protagonists' guilt or fate is provoked, instilled and determined by the power relations of the society they live in, and by the explicit or implicit violence of their husbands and fathers. This is more apparent in this play than in other Middletonian ones (except maybe Hengist, where another Castiza is the innocent victim of male intrigues: but Castiza in Hengist is another specimen of the helpless, innocent heroine who cannot save herself and is passively destroyed in the process). The Tyrant, after having inflicted his wife Thetis the awful punishment, is attacked by his enemies, but before dying kills her, laughing heartily at his victory; so what we are left with in the end is the cold, cruel laughter of the powerful male, and the image of the silent woman subjected to intolerable violence from someone who had sworn to protect her and love her, no matter what happened.

Let us conclude with the fourth and last tragedy of the new canon, The Second Maiden's Tragedy, recently renamed The Lady's Tragedy ${ }^{15}$. The case of its female protagonist is certainly an important one, in connection with the element we are commenting: "the Lady" is a regal, Lucrece-like character, of a spotless almost superhuman quality which is certainly very far from what we used to expect from our author. She is almost too good to be truly Middletonian, and one can understand why some critics denied his authorship: no character in the author we used to know would be so free from human weaknesses, so spotless, so perfect. The key to the question is that here no psychological vraisemblance is required: perfection is needed in the character because her main function is to die. Nihil de mortuis nisi bene: she dies in the first scene of the third act, and is created to be a saintly, virtuous and Roman-like heroine, a kind of undefiled Lucrece, who is loved to excess by both male protagonists, and who is to appear as a ghost to urge her lover to defend her body; in the end she will be instrumental to the restoration to the throne of the rightful heir.

She is completely free from faults. But she is not a sheer occasion of revenge; she is the pivot of the play: the two male characters - prince and usurper, rightful heir to the throne and tyrant, promised husband and unrequited, violent lover - define themselves more in relationship with her than in their own public role: so much so that they have been defined with the terms of "weak males" of "softened masculinity" 16 . Both are much more interested in obtaining or keeping her love than in the state; Govianus, the prince, easily bears the loss of the throne because the Lady remains with him; the Tyrant explicitly declares that the throne itself is of no interest, if she is elsewhere. When the Tyrant tries to convince her to abandon her lover, she resists with adamant strength; when he decides to have her by force, she asks Govianus to kill her, and when he cannot do it, and faints - as so many weak heroines did before him - she bravely stabs her own bosom. The most interesting part of the play starts with her death: the Tyrant has her body abducted from her tomb, plans to have her embalmed and fondles her corpse with necrophiliac passion. At this point, as happened to The Revenger's 
Tragedy's Castiza, the Lady is given by Middleton another role generally reserved to male characters (as he did in The Ghost of Lucrece): she appears as Ghost to denounce the profanation, ${ }^{17}$ and asks Govianus to protect her body.

Here we find an important and very effective aspect from the performance point of view. There are two elements which the author must have found intriguing: first, in a time when only very simple special effects where available, the illusion of having a dead person and her body simultaneously present on stage is theatrically very effective: even the name of the boy actor, Richard Robinson, survives in the stage direction, because of course it was essential for the ghost to be recognized as the Lady. On the other hand, there is a keen metaphorical interest in the symbology of black and white in the description of the Lady and her Ghost.

Both interests of the playwright are revealed by the unusually detailed stage directions depicting the three different appearances of the Lady, as a ghost, as a body without life, and as a ghost accompanying the body. When she appears in the violated Church, this is her description:

[I]n a kind of noise like a wind, the doors clattering, the tombstone flies open, and a great light appears in the midst of the tomb; his LADY, [...], standing just before him all in white, stuck with jewels and a great crucifix on her breast. (IV.iv) ${ }^{18}$

Later, this is the description of her corpse in the sinful hands of the Tyrant:

[D]ressed up in black velvet which sets out the paleness of the hands and face, and a fair chain of pearl across her breast and the crucifix above it. (V.ii)

As we know, stage directions in early modern plays were sparse and concise; here the precise aspect of the Lady, including the fabric and the colour of her dress, are quoted in detail.

Then the Ghost appears again:

Enter the Ghost in the same form as the Lady is dressed in the chair (V.ii)

Here, the effect of the double Lady, corpse and living soul, is to be heightened by the physical identity; and in fact, when Govianus poisons the Tyrant and she is pacified,

The Spirit [of the LADY] enters again and stays to go out with the body, as it were attending it (V.ii)

So, what Middleton is concentrating on at this point is both the scenic and the spiritual effect of the identity of body and soul, represented by two boy-actors present on stage and pretending to be the same person; on the other hand, the manifold and changing appearances of the real tremulous body of the woman and of its triumphant living soul are expressed by the rich interplaying images of black and white: the glorious white brightness of the soul, the livid white of her dead face and hands, the crucifix on both, the jewels of the beatific image and the pearls (white on black) of the helpless relic.

31 This is the utmost level at which a female positive character is symbolic and central in Middleton, even though, for a keen psychological analysis and a fully human complexity, we will have to wait for the return of negative heroines, the protagonists of Women Beware Women and above all The Changeling. Roxena and Castiza in Hengist add little to the development of female characters in Middleton's new canon. But certainly our appraisal of the psychological complexity of the "fair murderess" Beatrice-Joanna is heightened by the knowledge of what preceded her, and by the new, central datum 
that a heroine in 'the new' Middleton is often a complex character, who does not necessarily need to be a sinner, weak and incapable of seeing the reality of her own soul.

\section{NOTES}

1. A slightly different version of this paper was published with the title "The New Canon of Thomas Middleton" in Laura Di Michele (ed.), Regenerating Community, Territory, Voices. Memory and Vision, Napoli, Liguori, 2 vols., vol. I, 2012.

2. M.P. Jackson, in particular Studies in Attribution: Middleton and Shakespeare, Salzburg, University of Salzburg, 1979; D.J. Lake, The Canon of Thomas Middleton's Plays, Cambridge, Cambridge University Press, 1975; R.V. Holdsworth, Three Jacobean Revenge Tragedies, London, Palgrave MacMillan, 1990, 1991.

3. Gary Taylor, John Lavagnino et alii (eds.), Thomas Middleton: The Collected Works and Companion (Thomas Middleton and Early Modern Textual Culture. A Companion to the Collected Works), Oxford, Clarendon Press, 2007, 2 vols.

4. Cf. Una Ellis-Fermor, The Jacobean Drama, 1936, London, Methuen, 1965, p. 152; Michael Taylor (ed.), "Introduction" to Thomas Middleton, A Mad World, My Masters, and other Plays, The World's Classics, Oxford and New York, Oxford University Press, 1995, p. xiii.

5. Gary Taylor, Introduction to The Widow, in Taylor and Lavagnino (eds.), op. cit., vol. 1, p. 1074.

6. Please find marked in bold all the changes in the Middleton canon: most important, plays now attributed to Middleton and plays formerly attributed to him which have recently been assigned to other authors. When the presence of a co-author is confirmed, it has not been reported. Changes in genre and in dates of composition have also been highlighted in bold.

7. On Hengist see first of all the important work by Grace Ioppolo, who has written extensively on the play: Grace Ioppolo (ed.), Hengist, King of Kent, or The Mayor of Queenborough, Oxford, Oxford University Press, 2003; "Revision, manuscript transmission and scribal practice in Middleton's Hengist, King of Kent, or, The Mayor of Queenborough", Critical Survey 7, 3, 1995, 319-331; her introduction to the edition of Hengist, King of Kent; or The Mayor of Queenborough, in Taylor and Lavagnino (eds.), op. cit., vol. 1, p. 1448-1451; her "Textual introduction and textual notes to the edition of Hengist, King of Kent; or The Mayor of Queenborough", in Taylor and Lavagnino (eds.), op. cit., vol. 2, p. 1029-1061. See also the article by Julia Briggs "Middleton's Forgotten Tragedy Hengist, King of Kent", The Review of English Studies, New Series, vol. 41, n 164, Nov. 1990, 479-495. Before these works, only Samuel Schoenbaum (Middleton's Tragedies. A Critical Study, New York, Columbia University Press, 1955, and Internal Evidence and Elizabethan Dramatic Authorship: An Essay in Literary History and Method, Evanston, Northwestern University Press, 1966) gave Hengist an important role in Middleton's production, linking it to the great tragedies also from the point of view of artistic achievement, in an essay rich in fertile insights into Middleton's work but with what appears to me an overestimation of the play's merits. A study by Tommaso Continisio and the present writer, "Some Middletonian Queens: The Lady's Tragedy and Hengist", in Bianca Del Villano (ed.), Queens on Stage. Female Sovereignty, Power and Sexuality in Early Modern English Theatre, Roma, Aracne, is forthcoming.

8. Even Celia R. Daileader has to admit this in her essay "Thomas Middleton, William Shakespeare, and the Masculine Grotesque", in Gary Taylor and Trish Thomas Henley (eds.), The 
Oxford Handbook of Thomas Middleton, Oxford, Oxford University Press, 2012, p. 452-468, which favourably compares Middleton's attitude with Shakespeare's on this specific point of view.

9. All the quotations from Middleton's works are taken from Taylor and Lavagnino (eds.), op. cit., vol. 1.

10. See Celia R. Daileader's excellent essay “'Writing Rape, Raping Rites': Shakespeare's and Middleton's Lucrece Poems," in Violence, Politics, and Gender in Early Modern England, Joseph P. Ward (ed.), New York, Palgrave Macmillan, 2008, p. 67-86, and my forthcoming essay on the two Lucreces, which will be presented at the Conference Shakespeare 2016. Memoria di Roma, Rome, April 2016.

11. For the use of names in Middleton, see the articles "Middleton's Way with Names" by William Power, Notes and Queries, January 1960, 26-29, February 1960, 56-60, March 1960, 95-98, April 1960, 136-140, May 1960, 175-179.

12. William Shakespeare, King Lear, R.A. Foakes ed., The Arden Shakespeare 2001, IV.vi.33-34.

13. Helena in All's Well that Ends Well is also an active character, pretending to be someone else in the bed-trick scene and spreading the rumour she is dead; also Hermione in The Winter's Tale pretends to be dead (again not a very active role) and disguises as a statue. The case of Portia, though, is certainly much more definite.

14. There are a few reasons why I refer to Ophelia here. First of all, the transformation of Thetis from a powerful, proactive protagonist into a passive one, accepting her penalty in silence, curtseying to bystanders, eating and drinking her horrible meal without any perceptible reaction, makes me feel that Middleton planned a purposeful shift from his former powerful female protagonist to an obedient, passive one, of which Ophelia is an epitome. Besides, in the Elizabethan iconography loose hair implies madness: there are of course various madwomen in Elizabethan plays, but again I think that Ophelia's figure is paradigmatic, and therefore probably present in Middleton's mind in designing this portrait.

15. For details about the title of the play, see Julia Briggs, "The Lady's Tragedy: Parallel Texts", in Taylor and Lavagnino (eds.), op. cit., vol. 1, p. 833-838; volume 2, p. 619-621; Anne Lancashire (ed.), The Second Maiden's Tragedy, Manchester, Manchester University Press, The Revels Press, Johns Hopkins University Press, Baltimore, 1978.

16. Kevin Crawford, “'All His Intents Are Contrary to Man': Softened Masculinity and Staging in Middleton's The Lady's Tragedy", Medieval and Renaissance Drama in England, 16, 2003, 101-129; Rebecca W. Bushnell, Tragedies of Tyrants. Political Thought and Theater in the English Renaissance, Ithaca and London, Cornell University Press, 1990.

17. About the presence of murdered bodies on the early modern stage, see the study by Susan Zimmerman The Early Modern Corpse and Shakespeare's Theatre, Edinburgh, Edinburgh University Press, 2005, 2007, in particular the chapter "Animating Matter: The Corpse as Idol in The Second Maiden's Tragedy and The Duke of Milan", p. 90-106.

18. Here and in the two following quotations, the emphasis is ours.

\section{ABSTRACTS}

The traditional vision of Middleton as a playwright depicted him as an author of city comedies and tragicomedies, who in his very last years suddenly approached the tragic genre. Among his last four plays, three composed in succession are tragedies: Hengist, 1620, Women Beware Women, 
1621 and The Changeling, 1622; the last two are recognized as masterpieces. In the last forty years, Middleton's canon has changed with new attributions. This paper analyses the new pattern emerging in Middleton's work with the insertion of the plays that have been attributed to him in the last few decades, remarking how tragedy is present throughout his career (A Yorkshire Tragedy in 1605, The Revenger's Tragedy in 1606, The Bloody Banquet in 1609 and The Lady's Tragedy in 1611). This sheds now light on his status as a playwright; in this paper, I try to analyse how the pattern of his female characters can be read with much richer insights considering the development of his tragic protagonists from 1605 to the end of his production.

Traditionnellement, le dramaturge Middleton est représenté comme un auteur de comédies et de tragicomédies citadines qui se serait soudain tourné vers le genre tragique à la toute fin de sa vie. Trois de ses quatre dernières pièces sont des tragédies: Hengist, 1620, Women Beware Women (Femmes, gare aux femmes, 1621) et The Changeling (La Fausse Épouse, 1622), ces deux dernières étant reconnues comme des chefs-d'œuvre. Au cours des quarante dernières années, de nouvelles attributions sont venues s'ajouter au canon middletonien. Cet article analyse les reconfigurations de ce canon suite aux récentes attributions à Middleton de pièces qui témoignent de la présence constante de la tragédie tout au long de sa carrière (A Yorkshire Tragedy, 1605; The Revenger's Tragedy [La Tragédie du vengeur], 1606; The Bloody Banquet, 1609; The Lady's Tragedy, 1611) et invitent à voir sous un nouveau jour son activité de dramaturge. Le cas des personnages féminins, qui sont le sujet de cet article, permet de mieux comprendre le développement des personnages tragiques de Middleton entre 1605 et la fin de sa carrière.

\section{INDEX}

Mots-clés: canon, Middleton Thomas, personnages féminins, tragédie

Keywords: female characters, Middleton Thomas, new canon, tragedy

\section{AUTHOR}

\section{DANIELA GUARDAMAGNA}

University of Rome "Tor Vergata" 